\title{
Synthetic phonics, the digital humanities, and the teaching of beginning learners of English
}

\author{
Fonik Sintetik, Kemanusiaan Digital dan Pengajaran Bahasa Inggeris di Peringkat \\ Permulaan
}

\author{
Zuraidah Mohd Don ${ }^{1 *}$, \& Gerald Owen Knowles ${ }^{2}$ \\ ${ }^{1}$ Akademi Bahasa, Fakulti Sains Sosial dan Kemanusiaan, UTM, Johor \\ ${ }^{2}$ Penyelidik Bebas \\ *email: zuraidah.mohddon@utm.my
}

Published: 28 December 2021

To cite this article (APA): Mohd Don, Z., \& Knowles, G. O. (2021). Synthetic phonics, the digital humanities, and the teaching of beginning learners of English. EDUCATUM Journal of Social Sciences, 7(2), 1-9. https://doi.org/10.37134/ejoss.vol7.2.fa.1.2021

To link to this article: https://doi.org/10.37134/ejoss.vol7.2.fa.1.2021

\begin{abstract}
Abstrak
Terdapat literatur penyelidikan yang kaya mengenai fonik dan topik topik yang berkaitan dengan fonik seperti celik fonemik (phonemic awareness) dan pengukuran faedah fonik untuk mencapai kejayaan dalam membaca di masa hadapan. Apa yang tiada ialah huraian fonik sebagai displin berlandaskan teori yang mantap. Artikel ini menjejaki bagaimana terjadinya situasi sekarang dan mengembalikan fonik ke tempat sebenar antara kajian bahasa lisan dan kajian membaca. Masaalah yang timbul akibat situasi sekarang terletak di bahu guru di dalam bilik darjah yang mungkin perlu mengajar mengguna metod pengajaran tanpa dibimbing secukupnya tentang apa yang sepatut mereka lakukan. Mengambil pendekatan kemanusian digital yang berpusatkan guru, artikel ini mencadangkan suatu peranti yang boleh memberikan guru maklumat fonik mengenai bahasa Inggeris sama seperti kamus memberikan maknanya.
\end{abstract}

Kata kunci fonik, celik fonemik, pengajian membaca, kemanusiaan digital

\begin{abstract}
There is a rich research literature on phonics and related topics such as phonemic awareness and measurements of the benefits of phonics for later success in reading. What seems to be missing is a theoretically sound account of phonics itself as a discipline. This paper traces the way the present situation came about, and restores phonics to its true place between the study of spoken language and reading studies. The problems caused by the present situation fall on the shoulders of teachers in the classroom, who may be required to teach using phonic methods without being adequately guided on what they are supposed to do. Taking a teacher-centred "digital humanities" approach to phonics, the paper proposes a device that could provide the teacher with phonic information about English words much as a dictionary provides their meanings.
\end{abstract}

Key words: phonics, phonemic awareness, reading studies, digital humanities

\section{INTRODUCTION}

Several years ago, the Malaysian Ministry of Education chose synthetic phonics as the method to be used to teach beginning learners of English to read English. This was indeed a wise decision. However, the wisest of decisions for the teaching of young children are of no avail unless teachers are able to implement them in the classroom. The question that has to be asked is how many teachers understand exactly what phonics is all about, and can explain the difference between synthetic phonics and other approaches to phonics. 
Conscientious teachers make an effort to understand the principles behind what they do in the classroom, but in this case they are likely to get confused. Whether they read materials on the internet or conventional books and articles, they will find the same concept referred to by different technical terms, and the same terms used to define different concepts. They will find explanations of some areas of phonics, but what they will not find is a clear explanation of the role of phonics in the teaching of beginning literacy. This is because the knowledge has been lost. The Malaysian teachers who were trained at Kirkby College outside Liverpool in the 1950s and early 60s will have understood phonics, but they have long since left the classroom.

In fact, the knowledge required to understand phonics has been developed in other disciplines such as linguistics and phonetics, and more recently in brain science. It seems specifically in the teaching of early literacy that the knowledge is lacking. The purpose of this paper is to explain how this situation came about, and to report research which could lead to the development of a practical device that teachers can use in the classroom to provide the information they need. The next section deals with the background that led to the Phonics Wars of the last century and created the present problem. This is followed by a section dealing with methods and results of research to understand and address the problem; and the discussion is followed by the conclusion.

\section{THE BACKGROUND TO ENGLISH PHONICS}

English phonics is an ancient discipline which originated in the sixteenth century, and which in the nineteenth century began to face challenges from unscientific claims in favour of alleged alternative approaches to reading. In the last century, these challenges led to the Phonics Wars, from which phonics as a discipline has never recovered.

\section{The Phonics Wars}

English phonics began in the UK, and spread to countries such as the US and Australia. Among the most successful phonics teachers was the American Noah Webster, who in the late eighteenth century began to produce books known as "Blue-Backed Spellers", which were in use throughout the nineteenth century and into the twentieth. Teachers interested in phonics may know the book Why Johnny can't read (Flesch 1955), which reports growing opposition to phonics teaching. According to Flesch, publishers jealous of the success of Webster's books sought to introduce alternative approaches to reading, alas based on bogus and unscientific ideas.

In the first part of the last century, linguistics emerged as a new discipline within the humanities, and was closely connected with phonetics, the discipline concerned with speech and speech sounds. The difference between phonics and phonetics is that phonics is concerned with the relationship between spellings and speech sounds, whereas phonetics is concerned with the study of the speech sounds themselves. By the middle of the century, linguists and phoneticians had developed the theory of the phoneme (Jones 1950). Phonemes are the speech sounds represented by spellings, and phoneme theory made possible a great advance in the understanding of phonics. For reasons that are beyond the scope of this article to explain, linguistics and phonemes triggered off a widespread rejection of the study of language, not only in reading studies, but also in the study of English literature, and even in medieval history, which relies very heavily on the study of language.

In the following decades, at the time of the Phonics Wars, phonics was taken out of teacher training, with the result that newly qualified teachers were expected to teach beginning reading without the knowledge they required. Teachers were expected to study a growing literature hostile to phonics written by people who lacked the knowledge of the spoken language required to evaluate what they were attacking. In this climate, phoneticians no longer regarded reading studies as any part of their 
discipline. Eventually, the knowledge related to phonics teaching ceased to be possessed even by teacher trainers and lecturers, and the knowledge was lost within reading studies.

Of course, there were teachers who were faced with the practical task of teaching young children to read, and who knew perfectly well that beginning readers needed to be shown the relationship between the spellings of words and their pronunciation. Not having been given an organized introduction to phonics, they had to make do with what they thought they understood, and the long-term result is the use of phonics full of mistakes and the confusion that characterizes phonics materials on the internet, in curricula, and elsewhere. The teachers are of course not to blame, because they and their students are the victims of destructive acts perpetrated several decades ago.

\section{Brain science}

Our understanding of reading, particularly beginning reading, has been transformed in recent decades by the study of reading in the brain (Dehaene 2009). Reading begins when the reader scans a line of print, and an image of the written text is sent from the eye to the brain. The first task for the brain is to analyse the image, and in the case of an alphabetic writing system, this means recognizing the image as a sequence of letters. So if the eye sees the word durian, the brain recognizes the string of letters "d, u, $\mathrm{r}, \mathrm{i}, \mathrm{a}, \mathrm{n}$ ". This process is known as letter recognition, and it is not really part of phonics, although it is sometimes confused with phonics, and letter recognition tasks are often mixed in with phonic exercises. Although it has been claimed in the past that readers can read words by recognizing the overall shape of the written word on the page, brain science has shown this to be untrue. Beginning readers have to know their letters before reading words.

The next task for the brain is to associate the string of letters of the spelling with the string of sounds that makes up the pronunciation. This is the stage that corresponds to phonics. Readers who have worked out the sounds can read the word aloud, and this is how teachers test whether children can read words or not. The pronunciation leads on to the meaning, so that the reader who can read a word aloud can also get to the meaning. However, here there is a major problem that is often overlooked in approaches to phonics, because readers can only access the meaning of words they already know. Just reading aloud a word like sesquipedalian gives no indication of its meaning (it actually means 'one and a half feet long'). Children who are learning to read their first language will already know the words they are expected to read, especially in the early stages. Those learning to read a new language need to be given from the very beginning the meaning of the words they are reading. For this reason, phonics courses which are designed for children who already know English are inappropriate for children who are also beginning learners of English as a second or foreign language.

If the brain does phonics, there can be no reasonable justification for not using phonics in the teaching of early reading. Nevertheless, it might be argued that some people successfully learn to read without phonics, and so phonics cannot be essential. In order to understand this, we have to distinguish between the conscious and the unconscious brain (Dehaene 2014). We learn many things unconsciously, without being aware of what we are learning. Young children acquire their first language unconsciously long before they can understand what they are learning, and they cannot explain their linguistic knowledge. When we speak, our words are accompanied by prosody, which includes the rise and fall in the pitch of the voice. We know exactly how to use prosody, but cannot explain it, because it is unconscious knowledge. Children who are not taught using phonics can still learn phonics rules, but they have to do so unconsciously, so that they are unlikely to be able to use their knowledge to develop their reading skills.

We are consciously aware of something when we give it our attention. Young children pay attention to the details of the letters when learning the alphabet, and are then able to say what they have learnt. The essence of knowledge gained through education is that we are consciously aware of it and can report what we know, for example for a test or in an examination. Teachers cannot teach the whole of a language, but what they can do is to give their students the essential information they need to carry on learning for themselves, to become autonomous learners. Phonics enables beginning readers to work 
out the pronunciation of many new words for themselves, and so take the first step towards autonomous language learning.

\section{"Whole word" and "whole language"}

When we first learn to do something, we have to pay conscious attention to every detail; for example when we learn to swim, we have to pay attention to moving our arms and legs in the water while breathing. When we reach a certain level of competence, we no longer have to pay conscious attention, so that we can think about something else while we are swimming. Beginning readers have to pay attention to the details of letters and letter combinations in order to read a single word, but more advanced readers seem to take in a whole word at once, which leaves them more time to think about what the word means.

Reading whole words at a time is a level of competence that teachers want their students to achieve. However, it has in the past been taken to be a method of teaching reading as an alternative to phonics. So-called "sight words" are associated with the work of Edward Dolch (1948). Dolch word lists are still much in use, and include graded word lists, frequent words, and "sight words", which allegedly cannot be sounded out or handled by phonic rules, and which therefore need to be read as a whole from the beginning.

To understand what whole word reading means, imagine an experiment in which volunteers repeatedly heard a recording of the word cat when "jfqc" was displayed on a screen, and then heard $d o g$ when "alzym" was displayed. Eventually they would associate the spellings with the pronunciation, and be able to say cat when "jfqc" was displayed alone, and write "alzym" when hearing the word dog spoken on its own. In this writing system, there would be no connection at all between the spelling and the pronunciation, and the spellings of different words would not be connected in any way. Each word would be unique and would have to be learned individually. Learning the thousands of words that beginning readers have to recognize would be an enormous task. It might well be possible, because it has nothing specially to do with reading, and involves associative learning, like associating stopping with a red light, or a meal with the smell of cooking.

English spellings are of course nothing like this at all. There are known connections between spellings and sounds, and words related in sound are generally related in spelling. Connections between spellings and sounds require sounds, and if sounds are ignored, the spellings have nothing to connect with, and "jfqc" is just as good a spelling as "cat". Although there are irregular spellings and many of them, and this certainly complicates the task of linking the spelling to the pronunciation, the general principle that pronunciation and spelling are connected still stands. It is the task of phonics to make these connections explicit by means of phonic rules. Whole word reading is a skill developed by the successful reader, not a property of words. All spoken words are made up of phonemes, and can therefore be sounded out. The spellings of all English words can be related to the pronunciation by phonic rules, although the rules are in some cases complex, and possibly for perfectly laudable reasons unknown to the teacher. "Whole word" is not a theory of reading at all.

The "whole language" approach began with an enlightened view of education associated with such figures as Comenius and Dewey, and sought to encourage reading for meaning, knowledge and enjoyment. This too is a level of competence which teachers want their students to achieve, and which has been confused with an alternative method of teaching reading. The approach is associated in particular with the work of Goodman (1967), who emphasised the role of top-down information in understanding a text, which is certainly important for understanding any aspect of language, but who failed to connect top-down with bottom-up information, and implied that readers could guess their way to the understanding of a text without it. Goodman dismissed the recognition of letters, corresponding sounds and words without adequate justification, and claimed a connection with the early work of Chomsky. Chomsky's early work (Chomsky 1957, 1965) is concerned with transformational-generative grammar, and has nothing whatsoever to do with the whole language approach to reading. Although Goodman's approach was highly influential in the last third of the last century and into the present century, it has nothing to recommend it, and is a good example of a bogus unscientific theory. 


\section{METHODS AND RESULTS}

The prehistory of this project began in about 1980, when one of the present writers was moderator for an MA in Reading Studies at a university college in the UK, and encountered an irrational lack of interest in the spoken language. The associated reading included vehement attacks on phonics by writers who revealed their lack of knowledge of the spoken language and of the discipline they were attacking. This was the time of the Phonics Wars, and nothing could be done about it. Both writers later became involved in consultancy for English phonics teaching at preschool level in Malaysia, and discovered that the problems of the Phonics Wars had been faithfully exported to Malaysia. Without an understanding of spoken English, it was quite impossible for Malaysian teachers and materials producers to handle English pronunciation accurately, or to use terminology appropriately. As the internet continued to grow, it became increasingly clear that the problem was widespread in Asia and across the globe. An incidental problem that this creates is that it makes it difficult to cite work in phonics. Leaving aside the two well-known cases cited above, there is no question of citing opinions that are scientifically misconceived, and it would be odious to cite the work of conscientious teachers who have published their work in good faith, or uploaded it to the internet, just to draw attention to its shortcomings. The first stage of research was therefore to make a general anonymous assessment of the state of the art in English phonics.

The next stage was to examine phonics as a discipline, and identify the key concepts and procedures, ensuring that technical terms were used correctly to label the right concepts. Here there was another problem. There is so much confused and misleading phonic material on the internet that the findings of research would most probably just go on the haystack, and have no effect whatsoever. Fortunately there is a way forward. Traditional work in the humanities can be re-worked using computational techniques in the context of the so-called digital humanities. Phonics can be presented much more clearly on the computer or smartphone screen than in traditional publications, and there is no limit to the number of examples that can be made available. Phonic rules can be presented systematically, so that teachers can acquire a good overall understanding of the discipline, or phonics support can be given for a specific vocabulary list, so that teachers and their students can be confident that they know the pronunciation of new words, as well as their meaning. Phonics is presented on a simple frame consisting of rows and columns, for which the prototype is already working, and having no name, is here called simply PhonFrame.

Since people new to the study of the spoken language tend to confuse speech sounds with the letters of the spelling, this is the place to start. PhonFrame presents the spelling on one row and the pronunciation on another. The spelling has of course no sound, but when the pronunciation row is clicked, a recording of the pronunciation is played. So far, this just like an on-line pronouncing dictionary.

The pronunciation of words is by convention presented using a phonetic alphabet of symbols which represent the phonemes which make up the pronunciation, e.g. bread /bred/ (where "/" marks the beginning and end of phonetic notation). Behind the scenes, PhonFrame has a pronouncing dictionary produced by a specially written program which uses the spellings of English words to compute the phonetic representation of their pronunciation. There are many possible phonetic alphabets, but for British English there is a standard alphabet which has been in use for fifty years, and which is taken from Gimson (1962). Some of Gimson's symbols can be difficult to learn just by reading about them, but when displayed next to the spelling, they soon become familiar. This is also a good way of learning about the 44 phonemes of British English, and raising one's level of phonemic awareness.

Words can be spelt out by listing the letters of the spelling by name, and they can be sounded out by listing the phonemes. For example, send is spelt out "ess, ee, en, dee" and sounded out by listing the sounds of /s, e, n, d/. Listening to words spelt out and sounded out soon makes clear the difference between the letters and the phonemes, and once the difference is clearly understood, spelling out is no longer needed. The reverse of sounding out is known in phonics as blending, and /s, e, n, d/ is blended 
into the normal pronunciation /send/. While this may seem to be an obvious and trivial process, it is important because to pronounce a word one needs to know not only the constituent phonemes, but also how to put them together. Phonics is associated with reading, but blending lays the foundation for speaking skills. Failure to attend to blending can lead to pronunciation problems later on.

In simple cases such as send, one letter corresponds to one phoneme, but there are other more complex correspondences. In ship, the letters "sh" together correspond to the phoneme $/ \mathrm{J} /$, and this can be represented by writing the letters together without a comma, thus "sh, i, p" corresponding to $/ \int, \mathrm{I}, \mathrm{p} /$. The letter " $x$ " illustrates the rare reverse correspondence of one letter to two phonemes, as in box, in which " $\mathrm{b}, \mathrm{o}, \mathrm{x}$ " corresponds to $/ \mathrm{b}, \mathrm{p}, \mathrm{k} \mathrm{s}$. Seeing the way letters and phonemes are aligned makes phonics much easier than reading a theoretical explanation and then looking for examples. It is easier to understand the correspondence between "sh" and $/ \mathrm{g} /$ and then to be told that "sh" is called a digraph than to start with a theoretical definition of digraphs.

A key stage in the preparation of phonic materials is to align letters and phonemes. Alignments are created for PhonFrame by a program that compares the spellings and the phonemic representations of words and aligns them in accordance with phonic rules. These rules are often presented without any clear idea of where they come from, and in fact they are closely connected with alignment. PhonFrame represents a wide range of phonic rules simply by aligning the spelling with the pronunciation. Silent letters are represented by an empty space, e.g. build "b, u, i, l, d" /b, , I, l, d/. Magic e is more complex, because it has a special vowel and a final silent "e", so that whereas in $\mathrm{mad}$, "m, a, d" corresponds to $/ \mathrm{m}, æ, \mathrm{~d} /$, in made, "m, a, d, e" corresponds to /m, eI, d, /. The final comma and empty space looks rather odd here, but the representations are designed for the computer to process and not for humans to look at. PhonFrame presents the information in this section in a much more user-friendly way that unfortunately cannot be shown here.

\section{DISCUSSION}

A central point that has emerged in the foregoing sections is that the key to understanding English phonics is phoneme theory, and familiarity with the phonemes of spoken English.

\section{Phonemic and Phonological Awareness}

It is often claimed that phonemic awareness is a good indicator of later success in reading. However, it has not been possible so far to identify the research that shows this unambiguously to be the case. Part of the problem is that the concept phonemic awareness itself remains undefined and is used in different senses. Among the first things that undergraduates studying British spoken English have to become familiar with is the set of phonemes of Received Pronunciation ("RP"). If they have already achieved phonemic awareness as beginning readers, it is not clear why they have to achieve it all over again, especially as they are likely to be particularly successful readers. Phonemic awareness cannot be a single level of achievement and must be a scale, because undergraduates are brought up from a low level to a higher level. Beginning readers have to become aware of the general connection between the sounds they use in speech and the letters used in writing, and then of the correspondence between the sounds of the pronunciation and the letters of the spelling of individual words. Teachers using phonics and anyone producing materials for phonics needs to achieve phonemic awareness at least at the undergraduate level.

The term phonological awareness is used to refer to different selections of phonological phenomena, including phonemes but also syllables and words, which beginning readers are made aware of, and from which they benefit. Syllables belong to the spoken language, and are important because of the connection between initial consonant clusters such [tr] in train and [kw] in queen and the phonic concept of blending. The benefit is lost, however, if syllables are mistakenly treated as sequences of written 
letters, including "tr" as in train and "qu" as in queen. "Qu" is of course a digraph that corresponds to the phoneme sequence $/ \mathrm{kw} /$.

A phenomenon which is of great importance in the teaching of spoken English, but which is probably not included in phonological awareness, is word stress. English words have a characteristic stress pattern, which may have no corresponding pattern in languages outside Europe. The words beLOW and BILlow have the same phonemes but are stressed on different syllables. Many learners of English have problems with related words such as PHOtograph, phoTOgrapher and photoGRAphic, which are stressed on different syllables. Stress awareness is essential for speaking skills, and poor standards of spoken English can be traced in large measure to the lack of stress awareness.

\section{Synthetic Phonics and Analytic(al) Phonics}

There are several competing approaches to phonics, including synthetic phonics and analytic(al) phonics. Jolly phonics has been put forward as different approach, but is actually a variant of synthetic phonics. The only theoretically sound approach is synthetic phonics, and it begins where beginning readers are, facing the spellings of words. The spelling first has to be analysed, taking account of letter groups that have to be processed together. Ship can be spelt out "ess, aitch, igh, pee", but "ess aitch, igh, pee" (without a comma between "ess" and "aitch" to indicate their grouping together) is better. Letters and letter groups are then matched with the corresponding phonemes, and the word can be sounded out $/ \int, \mathrm{s}, \mathrm{p} /$. The phonemes are then blended to form the normal pronunciation $/ \int \mathrm{rp} /$.

Analytic(al) phonics is related to whole word in that it proceeds top-down from word level, but differs in that it is concerned with intermediate structures such as rhymes and the identification of the initial consonant or consonant group of the word, sometimes called the onset. The problem with this approach is that it is difficult to understand intermediate structures without understanding their constituent phonemes. Surely learners need to study synthetic phonics first. Analytical phonics is perhaps better regarded as a valuable approach to phonological awareness and as a contribution to the language arts, rather than as an approach to phonics.

\section{Phonics Teaching}

For teachers familiar with the phonemes of RP, and preferably familiar also with phonetic transcription, phonics as a discipline must be relatively straight forward. Sounding out and blending may be unfamiliar but are not difficult to grasp. The alignment of spellings and phonetic transcriptions is difficult to achieve in practice, but the principle behind it is easy to understand. Phonic rules are connected to these alignments. Beginning readers taught using phonics are given a good insight into the nature of the spoken language and its relationship to the written language, and to the concepts associated with phonemic and phonetic awareness. In this way, concepts and procedures fit together in a logical manner. The teacher who understands phonics in principle may well have problems with phonic practices in view of the confused use of technical terms, and the high incidence of elementary errors in learning materials. Materials produced for US English can also create difficulties for those teaching UK English.

For the great majority of teachers without this knowledge, the difficulties must be almost insurmountable, and are perhaps akin to trying to understand algebra without arithmetic. If, as seems often to be the case, the teacher encounters phonics when required to teach materials containing phonic rules, it must seem that arbitrary bits of spelling are somehow connected to arbitrary bits of speech sound. It must be difficult to understand an alignment without first understanding the items being aligned. For teachers in this position, it is difficult to distinguish speech and writing, or to achieve any deep understanding of concepts associated with phonemic and phonological awareness. The problems teachers face are entirely predictable given the lack of organization of phonics as a discipline, and they are not to be underestimated. 
PhonFrame can help teachers who do not understand phonics, and can do so in several different ways. Suppose the teacher is preparing a text on physical exercise, and finds that it contains some difficult words such as leotard, gymnast, and somersault. A dictionary can be used to ascertain the meanings, and it might also give the pronunciation; but unless the teacher is familiar with phonetic transcription, a pronunciation entry such as /liəta:d/ may not convey much at all. PhonFrame not only gives the phonetic transcription, but analyses the pronunciation into its constituent phonemes, so that the teacher is able to understand the pronunciation at a greater depth than is possible just by listening and imitating, and is in a stronger position to introduce new words to the class. The spelling of "leotard" is parallel to "leopard", which raises the question whether leopard should be pronounced /liəpa:d/; but PhonFrame confirms that it is pronounced /lepəd/, and so quite different from leotard. Listening carefully to contrasting spoken forms, being aware of the constituent phonemes, and memorizing the actual sounds of the words, is a richer and more real learning experience than just seeing them on the printed page.

The teacher who uses PhonFrame informally as a tool in lesson preparation will gradually become more aware of the structure of spoken English, and will become ready to tackle phonics systematically as a discipline. This involves reviewing the concepts and procedures introduced above and investigating phonic rules in detail, and understanding how English spelling works as a writing system. An introduction to phonics using PhonFrame is currently in preparation, and aims to give teachers more confidence in using phonic methods, and perhaps more importantly, the ability to use their knowledge to enable their students to become more successful readers. As always, understanding the nature of the spoken language requires informed listening, and not just reading. Reading is effective for understanding connections between the spoken and the written language when the listening has been done. If beginning readers of English are to associate the spellings of English words with their pronunciation, the task has to be seen as one involving not just beginning reading, but also beginning listening to spoken English.

\section{CONCLUSION}

This paper has traced the problems of phonics to the hostile rejection of linguistics as an emerging discipline in the middle of the last century, and in particular to the rejection of phoneme theory, which provides the very theoretical infrastructure on which phonics as a discipline is based. Phonics is a means to an end, to set beginning readers off effectively on the path to literacy. Phonic rules are in truth no more exciting than number bonds or the names of the days of the week, and there has long been a temptation to look for a short cut to reading, and eliminate the uninteresting but essential task of laying foundations. The consequence is that decades after the Phonics Wars, the discipline remains in a state of confusion, and conscientious teachers are expected to work miracles in the classroom without being given any clear idea of what it is they are trying to do.

If the problem was the rejection of phonemes, the solution is to bring them back. Teachers who are expected to teach English phonics need to know about the phonemes of English. The theory of phonetics has of course moved on in recent decades, but the state of the art as it was in the middle of the last century remains a suitable starting point for the understanding of phonics. Technology has also moved on apace since the 1950s, and it would now be inappropriate to expect teachers to read books and journal articles to find out about phonemes when there are better ways of delivering the information. This paper has also proposed a practical digital solution which could be developed as a smartphone app to provide teachers with information about the spoken language in much the same way as in the past they have used dictionaries to find out about the meanings of words.

\section{REFERENCES}

Chomsky, Noam. 1957. Syntactic Structures. The Hague: Mouton. 
Chomsky, Noam. 1965. Aspects of the Theory of Syntax. Cambridge, MA: MIT Press.

Dehaene, Stanislas. 2009. Reading in the Brain. New York: Viking.

Dehaene, Stanislas. 2014. Consciousness and the Brain: New York: Viking.

Dolch, Edward William. 1948. Problems in Reading. New York: Garrard Press.

Flesch, Rudolf. 1955. Why Johnny Can't Read. New York: Harper \& Row.

Gimson, A. C. 1962. An Introduction to the Pronunciation of English. London: Arnold.

Goodman, K. 1967. "Reading: A Psycholinguistic Guessing Game." Journal of the Reading Specialist (May):126-35.

Jones, Daniel. 1950. The Phoneme: Its Nature and Use. Cambridge: Cambridge University Press. 